\title{
Climate-change impacts and fisheries management challenges in the North Atlantic Ocean
}

\author{
Andrea Bryndum-Buchholz ${ }^{1, *}$, Daniel G. Boyce ${ }^{1,2}$, Derek P. Tittensor ${ }^{1}$, \\ Villy Christensen ${ }^{3}$, Daniele Bianchi ${ }^{4}$, Heike K. Lotze ${ }^{1}$
}

\begin{abstract}
${ }^{1}$ Department of Biology, Dalhousie University, 1355 Oxford Street, Halifax, NS B3H 4R2, Canada ${ }^{2}$ Ocean Frontier Institute, Steele Ocean Sciences Building, Dalhousie University, Halifax, NS B3H 4R2, Canada

${ }^{3}$ Institute for the Oceans and Fisheries, University of British Columbia, Vancouver, BC V6T 1Z4, Canada ${ }^{4}$ Department of Atmospheric and Oceanic Sciences, University of California, Los Angeles, CA 90095-1565, USA
\end{abstract}

\begin{abstract}
Climate-induced changes in the world's oceans will have implications for fisheries productivity and management. Using a model ensemble from the Fisheries and Marine Ecosystem Model Intercomparison Project (Fish-MIP), we analyzed future trajectories of climate-change impacts on marine animal biomass and associated environmental drivers across the North Atlantic Ocean and within the Northwest Atlantic Fisheries Organization (NAFO) convention area and evaluated potential consequences for fisheries productivity and management. Our ensemble results showed that the magnitude of projected biomass changes increased over time and from a low (RCP2.6) to high (RCP8.5) emissions scenario. Within individual NAFO divisions, however, projected biomass changes differed in the magnitude and sometimes direction of change between near (the 2030s) and far future (the 2090s) and contrasting emissions scenarios. By the 2090s, most NAFO divisions with historically (1990-1999) high fisheries landings were projected to experience biomass decreases of $5-40 \%$, while Arctic and subarctic divisions with lower historical landings were projected to experience biomass increases between 20 and $70 \%$ under RCP8.5. Future trajectories of sea surface temperature and primary production corroborated that the far-future, high-emissions scenario poses the greatest risk to marine ecosystems and the greatest challenges to fisheries management. Our study summarizes future trends of marine animal biomass and underlying uncertainties related to model projections under contrasting climate-change scenarios. Understanding such climate-change impacts on marine ecosystems is imperative for ensuring that marine fisheries remain productive and sustainable in a changing ocean.
\end{abstract}

\footnotetext{
${ }^{*}$ Corresponding author: andrea.buchholz@dal.ca
}

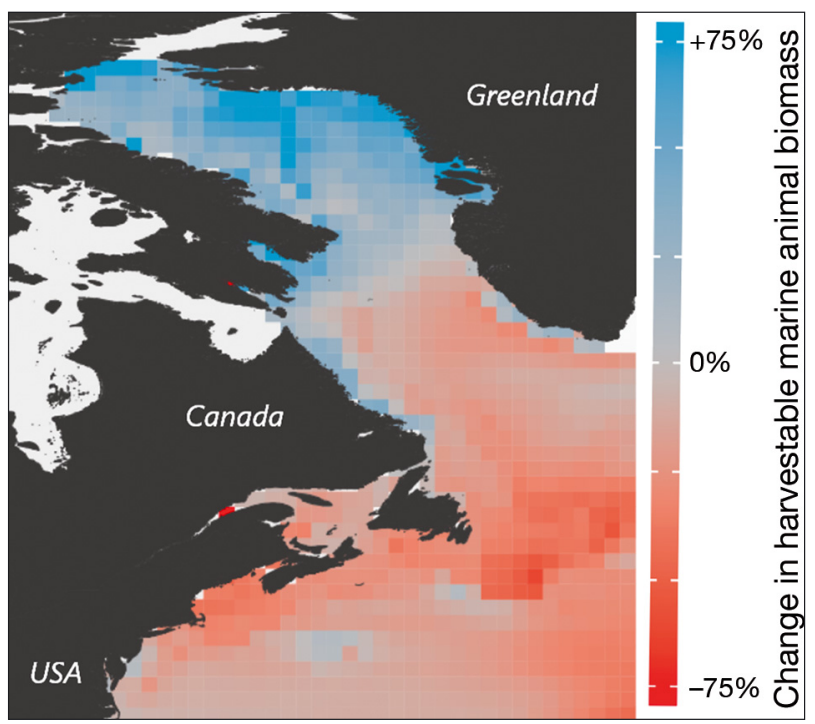

Projected changes in harvestable marine animal biomass under 21st century climate change in the NAFO convention area (high emissions scenario).

Image: A. Bryndum-Buchholz

KEY WORDS: Climate change $\cdot$ Animal biomass · Fisheries management - NAFO convention area · Ensemble modeling $\cdot$ Emissions scenarios · Marine ecosystem model $\cdot$ Fish-MIP

\section{INTRODUCTION}

Globally, climate change is impacting marine life, ranging from fundamental biological processes, such as growth, survival, and reproduction, to changes in the abundance and distribution of species, with con-

(C) The authors 2020. Open Access under Creative Commons by Attribution Licence. Use, distribution and reproduction are unrestricted. Authors and original publication must be credited. 
sequences for ecosystem structure and function (Poloczanska et al. 2013, Worm \& Lotze 2016, Lotze et al. 2019). Yet climate-change effects are spatially heterogeneous, with some regions experiencing much higher rates of changes (e.g. in sea surface temperature [SST], primary production) than the global average (Popova et al. 2016, Ramírez et al. 2017). As climate change alters the abundance and distribution of commercially targeted species, their spatial and temporal availability to marine fisheries is affected, with consequences for fishing operations and management (Cheung et al. 2010, McIlgorm et al. 2010, Blanchard et al. 2012, 2017). Thus, understanding future trajectories of marine animal biomass under climate change is critical for adapting fisheries management and marine conservation strategies.

The North Atlantic Ocean harbors extensive and productive fishing grounds, including the historically prominent Grand Banks and Flemish Cap off Newfoundland (Townsend et al. 2006, Castañeda et al. 2020). However, large areas in this region have already undergone significant cumulative climate-related changes in oceanographic conditions (Ramírez et al. 2017, Greenan et al. 2018) and have experienced substantial changes in regional fisheries production (Pershing et al. 2015, Britten et al. 2016). Such changes in regional fisheries production are thought to be influenced by regional climate change, fishing practices, a combination of both (Britten et al. 2016), and possibly associated regime-shifts (Frank et al. 2011, Pedersen et al. 2017, 2020). Failing to consider the interaction of fisheries management regimes and climate-change impacts in efforts to preserve the reproductive potential of commercial fish stocks can lead to regional fisheries collapses (Le Bris et al. 2018).

Water temperatures in the Northwest Atlantic, including surface, upper-ocean (0-300 m), and bottom temperatures, are warming at globally extreme rates and are projected to further increase nearly 3 times faster than the global average (Pershing et al. 2015, Saba et al. 2016). Hence, the Northwest Atlantic can act as an indicator of how ocean-warming effects may be manifested. Additionally, the enhanced ocean warming in the Northwest Atlantic has been accompanied by an increase in salinity and reduced oxygenation rates due to changes in water mass distribution related to the retreat of the equatorward-flowing Labrador Current and a northerly shift of the Gulf Stream (Saba et al. 2016, Claret et al. 2018). Ecosystem responses to these rapid changes in oceanographic conditions have important implications for living marine resources and their regional management. One prominent example of management chal- lenges in rapidly changing oceanographic conditions is the Gulf of Maine Atlantic cod Gadus morhua fishery, in which stocks were continuously overfished despite reduced recruitment and increased mortality in the region's cod population, as the impacts of warming were not adequately recognized in management metrics (Pershing et al. 2015).

The response of fisheries to ongoing climate change is only one consideration; for long-term fisheries development, national and international ocean governance and fisheries management also play an important role (Costello et al. 2016, Mullon et al. 2016, Galbraith et al. 2017). Effective management can provide a buffer against the impacts of a warming ocean. Few fisheries management authorities are in the process of integrating climate-change considerations in their management objectives, with traditional fisheries management measures being the favored approach (Soomai 2017, VanderZwaag et al. 2017). This highlights the need to provide comprehensive and accessible scenarios of long-term biological and ecological changes within respective regulatory areas to effectively work towards sustainable management of marine fisheries under climate change.

Fisheries in the North Atlantic Ocean are managed by international and national management agencies. For instance, the Northwest Atlantic Fisheries Organization (NAFO) is responsible for the management of high-seas fisheries (NAFO Regulatory Area), whereas fish stocks within the 200 nautical mile limit, representing each country's exclusive economic zone, are managed through respective federal governments - for example, in Canada through Fisheries and Oceans Canada (DFO) and in the USA through the National Oceanic and Atmospheric Administration (NOAA Fisheries). Fisheries management decisions are most often based on information from stock assessments that are used to set total allowable catches, fishing mortality limits, and regulate spatial or temporal fisheries closures (Cheung et al. 2019). With changing ocean conditions, the effectiveness of traditional management measures can deteriorate, as stock assessments rarely account for the effect of changing oceanographic conditions on population dynamics (Cheung et al. 2019). Consequently, to ensure long-term effective fisheries management, climate-change impacts need to be considered as part of management frameworks. Facing climate change, fisheries management organizations can make use of short- and long-term projections of changes in fish biomass and include information about climate impacts on populations to inform e.g. biological reference points for management. 
One approach to examining climate-change impacts on the ocean is to use marine ecosystem models to project future changes in animal biomass, species distribution, and food-web changes under different climate-change scenarios (Tittensor et al. 2018a). Combining individual model projections into ensembles allows the quantification of mean trends and, unlike single model assessments, the uncertainty in projected responses due to different model structures, parameters, and representations of ecological processes (Mora et al. 2013, Tittensor et al. 2018a). This need is particularly acute for marine ecosystem models, where the underlying heterogeneity of model types is substantial (Tittensor et al. 2018a).

The goal of this study was to analyze future trajectories of climate-change impacts on marine animal biomass across the North Atlantic Ocean and identify implications for fisheries productivity and management in the NAFO convention area. To do so, we utilized results from the Fisheries and Marine Ecosystem Model Intercomparison Project (Fish-MIP; Tittensor et al. 2018a,b) which provides outputs of marine animal biomass from 6 global marine ecosystem models that were forced by 2 Earth System Models under contrasting greenhouse gas emissions scenarios (also referred to as Representative Concentration Pathways, RCPs) following a standardized simulation protocol. The use of global models allowed us to cover the entire North Atlantic Ocean and NAFO convention area and to apply an ensemble modeling approach which provides an indication of the variation or uncertainty in projections (Tittensor et al. 2018a). We evaluated changes in marine animal biomass $>10 \mathrm{~cm}$, which can be interpreted as centers of secondary or harvestable biomass production, as well as projected changes in the major oceanographic drivers that may influence biomass trajectories. Lastly, we explored how projected ecological changes may affect fisheries distribution and production by analyzing the relationship between historical fisheries landings and projected biomass changes across NAFO divisions. Our results provide important long-term context for fisheries management and decision makers to plan for-and adapt to - changing ocean ecosystems into the future.

\section{MATERIALS AND METHODS}

\subsection{Study region}

This study focused on the projected impacts of climate change on marine animal biomass across the North Atlantic Ocean - to give a general context for expected ocean ecosystem changes - and within the NAFO convention area to evaluate the consequences for fisheries productivity and management.

\subsection{Data sources}

We derived spatially explicit historical (1970-2005) and future (2006-2100) projections of unfished marine biomass of animals $>10 \mathrm{~cm}\left(\mathrm{~g} \mathrm{C} \mathrm{m}^{-2}\right.$; vertebrates and invertebrates, excluding zooplankton; representing potentially harvestable biomass) from the FishMIP simulation round 2a (Fish-MIP v.1.0; Tittensor et al. 2018a,b). The time brackets related to historical (observed) and future (projected) periods as per the Earth System Model output for the Coupled Model Intercomparison Project Phase 5 (CMIP5) and similarly standardized for the Fish-MIP simulation protocol. Outputs of marine animal biomass were generated by 6 global marine ecosystem models with different ecological structures and processes (Table 1, Table S1 in the Supplement at www.int-res.com/ articles/suppl/m648p001_supp.pdf), each providing a standardized measure of bulk harvestable biomass production of animals $>10 \mathrm{~cm}$. Individual and combined ecosystem model outputs have been compared to empirical data across different temporal and spatial scales with generally good agreement (e.g. Blanchard et al. 2012, Christensen et al. 2015, Galbraith et al. 2017, Lotze et al. 2019).

Each ecosystem model was forced with standardized outputs from 2 Earth System Models under contrasting RCPs following the Fish-MIP simulation protocol (Tittensor et al. 2018a). The 2 Earth System Models, GFDL-ESM2M (Dunne et al. 2012) and IPSL-CM5A-LR (Dufresne et al. 2013), provided the necessary depth- and time-resolved physical and biogeochemical forcing variables required by FishMIP models (Table 1, Table S1, Tittensor et al. 2018a) and were derived from CMIP5 (https://esgf-node. llnl.gov/projects/cmip5/). However, GFDL-ESM2M did not provide the monthly depth-resolved phytoplankton and zooplankton data needed by DPBM and APECOSM, which were thus only run with IPSLCM5A-LR, resulting in $\mathrm{n}=10$ marine ecosystem model-Earth System Model combinations (referred to as 'model combination' hereafter). The GFDLESM2M and IPSL-CM5A-LR outputs span a wide range of projected Earth System changes under the specific RCPs, with GFDL-ESM2M representing moderate and IPSL-CM5A-LR strong changes in SST and net primary productivity (NPP), while other vari- 


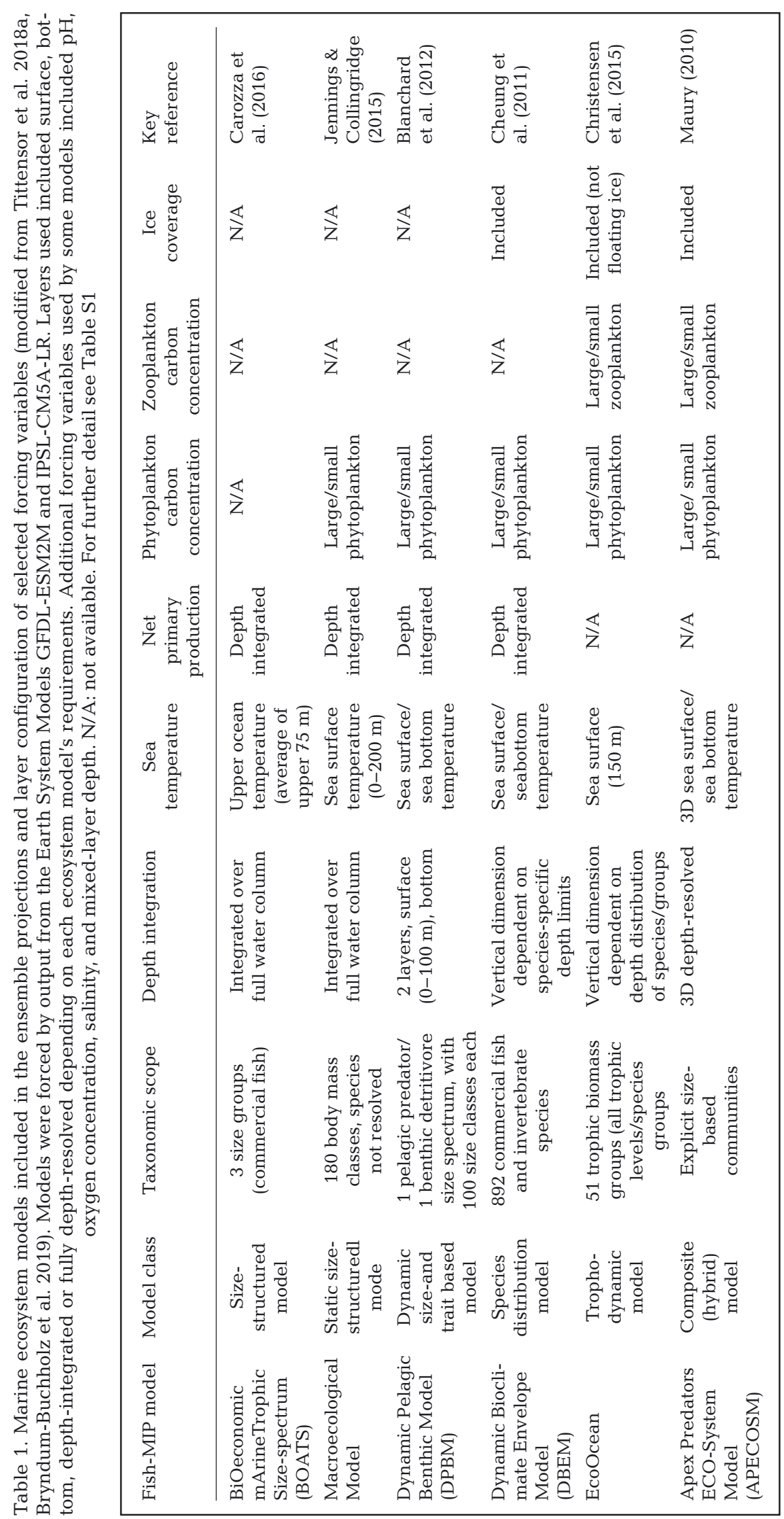

ables (e.g. $\mathrm{pH}$, oxygen concentrations) were more similar (Bopp et al. 2013). For our study, we selected RCP2.6 and RCP8.5 to bracket a broad range of greenhouse gas emissions trajectories. RCP2.6 represents a low emissions or strong mitigation scenario assuming emissions peak between 2010 and 2020 and decline substantially until 2100 (van Vuuren et al. 2011). RCP8.5 characterizes a no-mitigation and worst-case pathway assuming emissions continue to increase until 2100 (Riahi et al. 2011).

All ecosystem model projections were output on a $1^{\circ} \times 1^{\circ}$ global grid, except DBEM, which used a $0.5^{\circ} \times 0.5^{\circ}$ grid. Within Fish-MIP, future projections that included fishing impacts on animal biomass were only available for 3 of the 6 marine ecosystem models, and these used a very simplified future fishing scenario (i.e. fishing effort, mortality or exploitation rates, depending on model requirements, were held constant at 2005 levels) because spatially explicit future fisheries projections are as of yet unavailable in a standardized form. Hence, we chose to only analyze runs under a no-fishing scenario, thus focusing specifically on isolating climate-change impacts (Tittensor et al. 2018a).

We extracted annual total fisheries landings data from 19901999 for all fisheries and targeted species managed by NAFO for each division using the STATLANT 21A Data Extraction Tool (https://www.nafo.int/Data/

STATLANT). The 1990-1999 timeframe was chosen to correspond with our historical reference period in biomass projections (see Section 2.3). Additional time series (1980-1989, 20002009) for total landings were extracted for sensitivity analyses. 


\subsection{Data analysis}

\subsubsection{Projected changes in the North Atlantic Ocean}

Projected time series of historical and future marine biomass of animals $>10 \mathrm{~cm}$ for each model combination under RCP2.6 and RCP8.5 were extracted from the Fish-MIP database for the North Atlantic Ocean. We selected each grid cell centroid located in the North Atlantic Ocean (see Fig. 1) using ArcMap v.10.5 (ESRI) and calculated area-weighted annual mean biomass changes for each $1^{\circ} \times 1^{\circ}$ grid cell (which vary in size depending on latitude and longitude) using the statistical software $\mathrm{R}$ (v.3.4.3). DBEM's $0.5^{\circ} \times 0.5^{\circ}$ resolution was adjusted to a $1^{\circ} \times$ $1^{\circ}$ grid by averaging over each $1^{\circ} \times 1^{\circ}$ grid cell.

For each grid cell and model combination, we standardized annual biomass time series to percent change relative to the mean 1990-1999 biomass as a historical reference period for the last decade of the $20^{\text {th }}$ century. We then calculated mean percent biomass changes to 2030-2039 as a near-future time frame (the 2030s), which includes the target year 2030 of the United Nations Sustainable Development Goals (SDGs), and to 2090-2099 as the last decade of the $21^{\text {st }}$ century as a far-future time frame $(2090 \mathrm{~s})$ relative to the 1990s. We used calculations of relative rather than absolute biomass changes because different ecosystem models cover different components (e.g. size classes, trophic groups, species) of the marine ecosystem and their absolute biomass estimates are not directly comparable. These grid-cell specific relative changes were then averaged over all model combinations to derive an ensemble mean. We note that most grid cells contained a full ensemble $(\mathrm{n}=$ 10), except nearshore cells which often had $n=6$ or less (Fig. S1) due to differences in nearshore resolution and how land-sea masks are applied across models; however, previous sensitivity analyses comparing the full to reduced model ensembles did not drastically change the overall magnitude or direction of results (Bryndum-Buchholz et al. 2019, Lotze et al. 2019).

To evaluate the variability of individual projections around the ensemble mean, we used 2 measures: variability in the magnitude of projected relative biomass changes (\%), calculated as the standard deviation (SD, expressed as \% change) around the ensemble mean (referred to as model spread), and variability in the direction of projected changes (i.e. increase/decrease), calculated as the percent model agreement (Bopp et al. 2013). The model agreement can range between $50 \%$ (half the models in the ensemble agree on the direction of change) and $100 \%$ (all models agree on the direction of change). Generally, $80-100 \%$ represents high model agreement in the ensemble projections (Bopp et al. 2013).

\subsubsection{Projected changes in the NAFO convention area}

Within the NAFO convention area, we extracted spatially explicit ensemble mean biomass changes and calculated the model spread (SD) and percent model agreement for each NAFO division $(\mathrm{n}=35)$. We first mapped spatial patterns of projected changes in the ensemble mean biomass, and the model spread and model agreement across the NAFO convention area in the 2030s and 2090s relative to the 1990s under both emissions scenarios.

We used a similar approach to examine changes in historical and projected SST and NPP across NAFO divisions. We calculated mean relative changes in SST and NPP in the 2030s and 2090s relative to the 1990s for each Earth System Model under the 2 contrasting emissions scenarios and derived the ensemble mean $(\mathrm{n}=2)$ for each NAFO division. We then related changes in NPP to those in SST for each NAFO division to examine underlying shifts in oceanographic conditions under different climatechange scenarios.

\subsubsection{Relationship of projected biomass changes to fisheries landings}

To evaluate the potential impacts of future climate change on fisheries production, we related mean projected biomass changes (\%) from the 1990s historical reference period to the 2030s and 2090s for both RCP2.6 and RCP8.5 to mean total fisheries landings in each NAFO division during 1990-1999 (standardized by area, $\mathrm{kg} \mathrm{km}^{-2}$ ). The biomass projections and landings data both span the same area of interest and the 1990s baseline decade. We used weighted log-linear regression models to analyze the relationship between mean projected biomass changes (\%, dependent variable) and mean fisheries landings ( $\mathrm{kg}$ $\mathrm{km}^{-2}$, independent variable) across NAFO divisions (Eq. 1). We excluded NAFO divisions $6 \mathrm{~A}-6 \mathrm{H}$ from the regression analysis, as fisheries landings were only recorded for 1990-1992. Further, we log transformed the independent variable (fisheries landings) to satisfy statistical assumptions of linearity and a 
constant relationship between the variance and the mean for the residuals, based on a visual assessment. We accounted for the fact that some divisions showed higher model spread (SD) around the ensemble mean biomass change by adding inverse variance weights $(1 / \mathrm{SD})$ to the regression model. Larger weights were assigned to biomass projections with smaller SD, hence higher model agreement around the ensemble mean, giving them more influence in the regression analysis. The equation representing our modelling approach was thus:

$$
\Delta_{i}=\beta_{0}+\beta_{1} \log _{10}\left(L_{i}\right)+\varepsilon_{i}
$$

where $\varepsilon_{i} \sim \mathrm{N}\left(0, \sigma^{2} \omega_{i}\right), \Delta_{i}$ is the relative change in projected future biomass, $L_{i}$ is the average landings data within each NAFO division $i, \beta_{0}$ and $\beta_{1}$ are the estimated intercept and slope, respectively, $\varepsilon_{i}$ is the error term, $\omega_{i}$ the weighting for division $i$ (inverse variance weights), and $\sigma^{2}$ is the variance.

As a sensitivity analysis to account for variability in fisheries landings over time, we ran additional regression models with NAFO landings averaged over
1980-1989 or 2000-2009 instead; our results were robust to these differences.

\section{RESULTS}

\subsection{Projected changes in the North Atlantic Ocean}

Our ensemble projections of trends in marine animal biomass $>10 \mathrm{~cm}$ revealed much greater changes in the long term (by the 2090s) than in the near future (by the 2030s), and much greater changes under RCP8.5 than RCP2.6 (Fig. 1); biomass was generally projected to increase in Arctic and subarctic areas yet decline in most temperate and subtropical areas.

In the near future (the 2030s), projected changes relative to the 1990s showed spatially larger areas of biomass decrease under RCP8.5 compared to RCP2.6 (Fig. 1). Notably, a region between $40-50^{\circ} \mathrm{N}$ latitude off the western European coast showed consistently higher declines compared to other regions in the
A RCP2.6 2030s

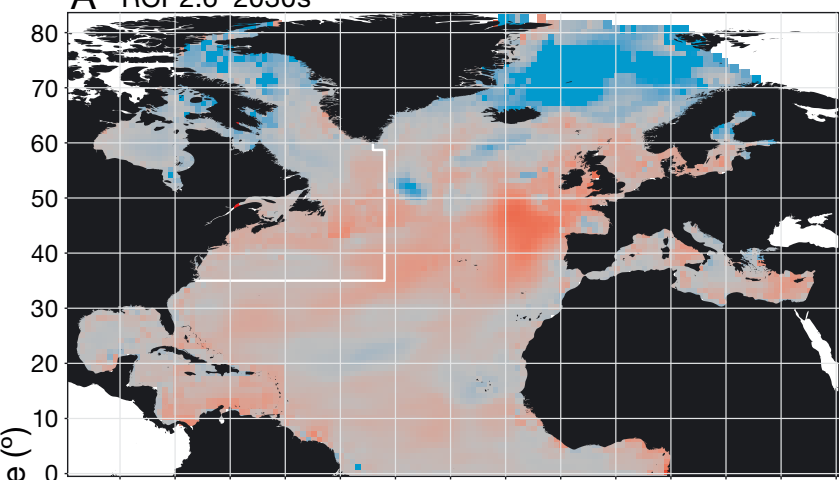

O C RCP8.5 2030s

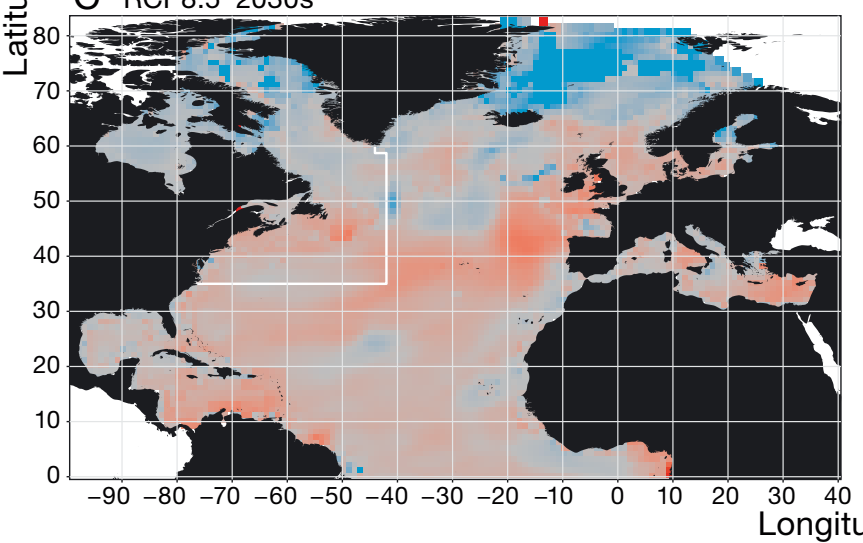

B RCP2.6 2090s

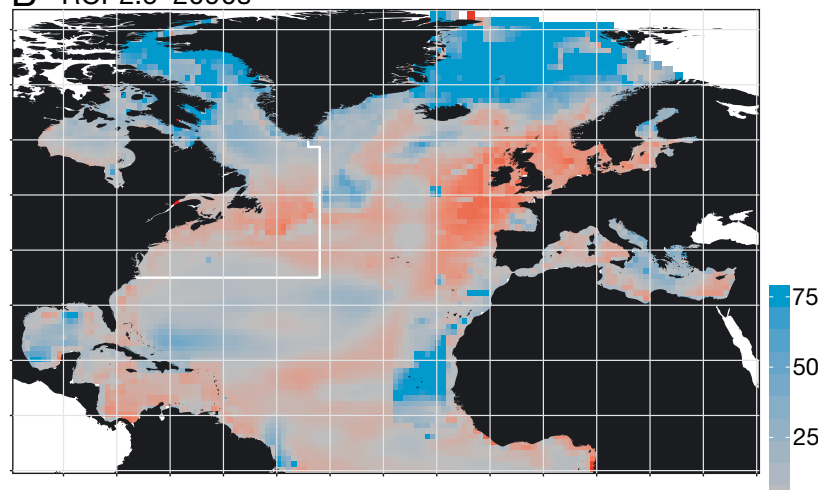

D RCP8.5 2090s

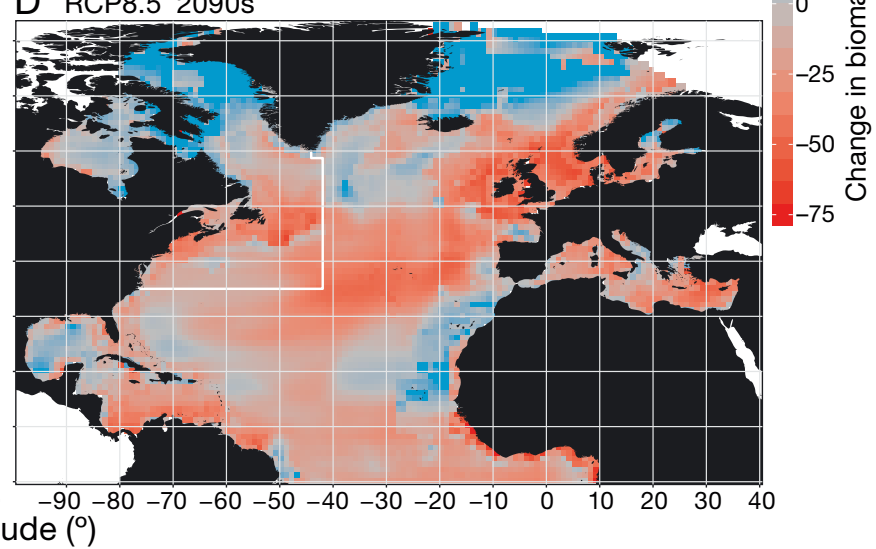

Fig. 1. Spatial patterns of ensemble projections for $(A, B) R C P 2.6$ and $(C, D)$ RCP8.5 in the North Atlantic Ocean. Shown are the multi-model mean changes (\%) in biomass of marine animals $>10 \mathrm{~cm}$ in the (A,C) 2030s and (B,D) 2090s relative to the 1990s. White outline: NAFO convention area. Country shapefile retrieved from https://www.naturalearthdata.com; NAFO convention area shapefile modified from https://www.nafo.int/Data/GIS 
North Atlantic under both emissions scenarios (Fig. 1). The model spread in the 2030s was lower under RCP2.6 than RCP8.5 (Fig. S2), with consistently high spread $( \pm 50 \% \mathrm{SD})$ above $60^{\circ} \mathrm{N}$ and in large parts of the Mediterranean Sea under both emissions scenarios. Model agreement in the direction of projected biomass changes by the 2030s was higher under RCP2.6 than under RCP8.5 (Fig. S2). Under RCP8.5, model agreement did not differ substantially between near- and far-future biomass changes (Fig. 2, Fig. S2).

In the distant future (by the 2090s), projected biomass changes under RCP2.6 generally followed a similar spatial pattern compared to near-future changes (Fig. 1). However, areas of projected biomass increase were larger and areas of biomass decrease smaller compared to RCP8.5, with overall lower magnitudes of change. Also, the model spread was lower under RCP2.6 and model agreement generally higher than under RCP8.5 (Fig. 2). Under RCP8.5, in the 2090s several areas of high biomass increase $(25-75 \%)$ occurred above $60^{\circ} \mathrm{N}$, off West

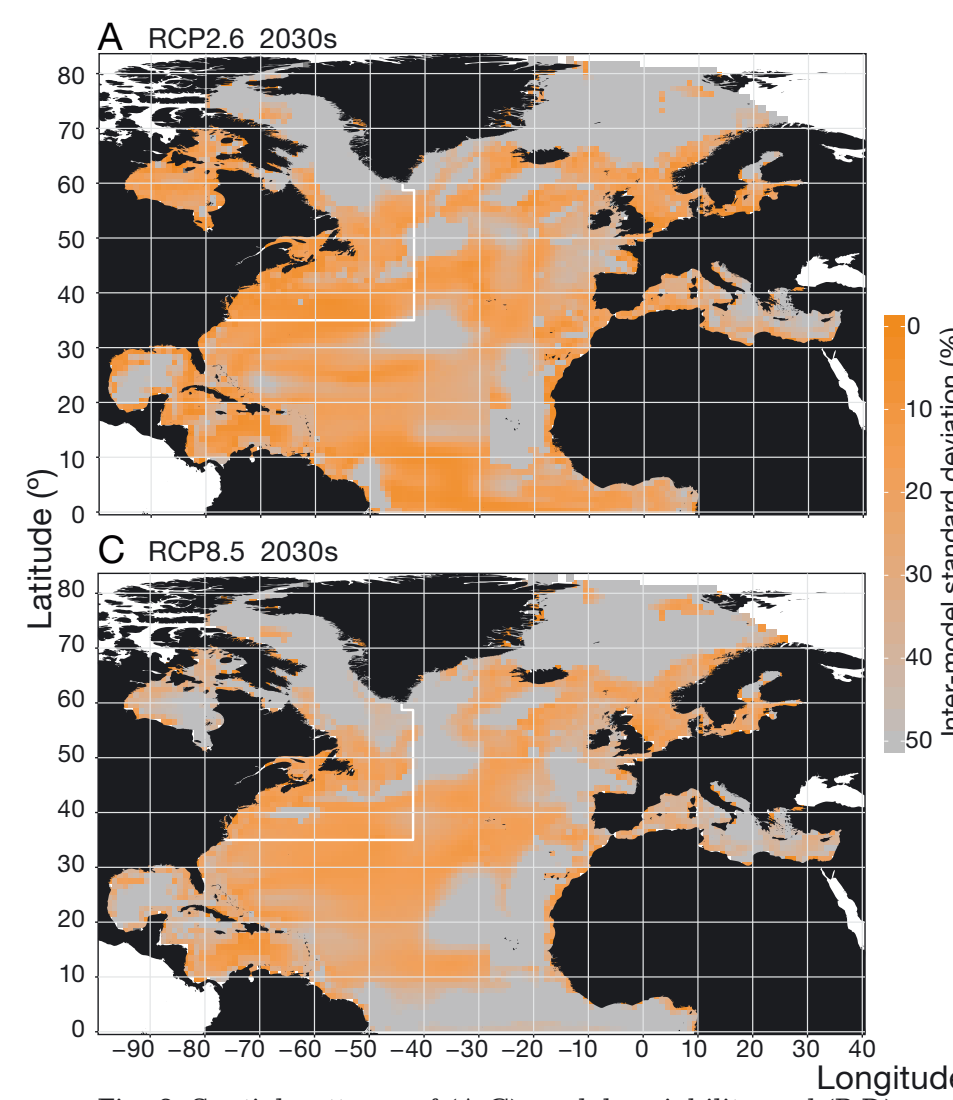

Africa $\left(20-30^{\circ} \mathrm{N}\right)$, and in the Gulf of Mexico (Fig. 1); however, they also showed high model spread $( \pm 50 \% \mathrm{SD})$ and low model agreement $(<80 \%)$ on the direction of change (Fig. 2). In contrast, areas of largest biomass decline were found between $35-60^{\circ} \mathrm{N}$, along the West African coastline $\left(0-10^{\circ} \mathrm{N}\right)$, and in most of the Caribbean Sea (Fig. 1), with low model spread (below $\pm 20 \% \mathrm{SD}$ ) and high model agreement $(>80 \%)$ providing confidence in ensemble results (Fig. 2).

\subsection{Projected changes in the NAFO convention area}

Projected changes in marine animal biomass $>10$ $\mathrm{cm}$, NPP, and SST across the individual NAFO divisions differed in magnitude and some cases direction of change between the near (the 2030s) and far (the 2090s) future relative to the historical reference period (the 1990s) as well as between the 2 emissions scenarios RCP2.6 and RCP8.5 (Figs. 3 \& 4, Fig. S3).

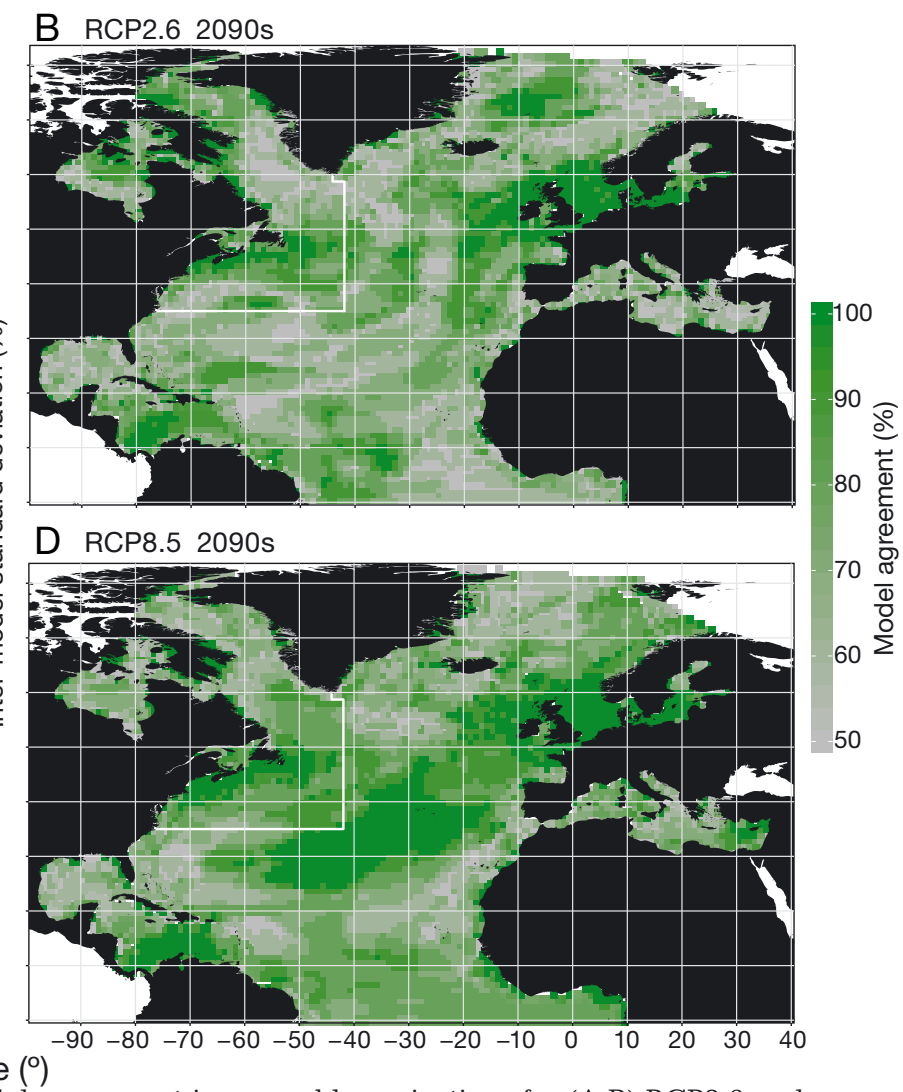

Fig. 2. Spatial patterns of $(A, C)$ model variability and $(B, D)$ model agreement in ensemble projections for $(A, B)$ RCP2.6 and (C,D) RCP8.5 in the North Atlantic Ocean in the 2090s relative to the 1990s. Model variability is represented as the inter-model standard deviation (expressed as \% change) of the projected ensemble mean biomass changes, while model agreement denotes the percent of models agreeing on the direction of change. White outline: NAFO convention area. Results for the 2030s are shown in Fig. S2. Country shapefile retrieved from https://www.naturalearthdata.com; NAFO convention area shapefile modified from https://www.nafo.int/Data/GIS 

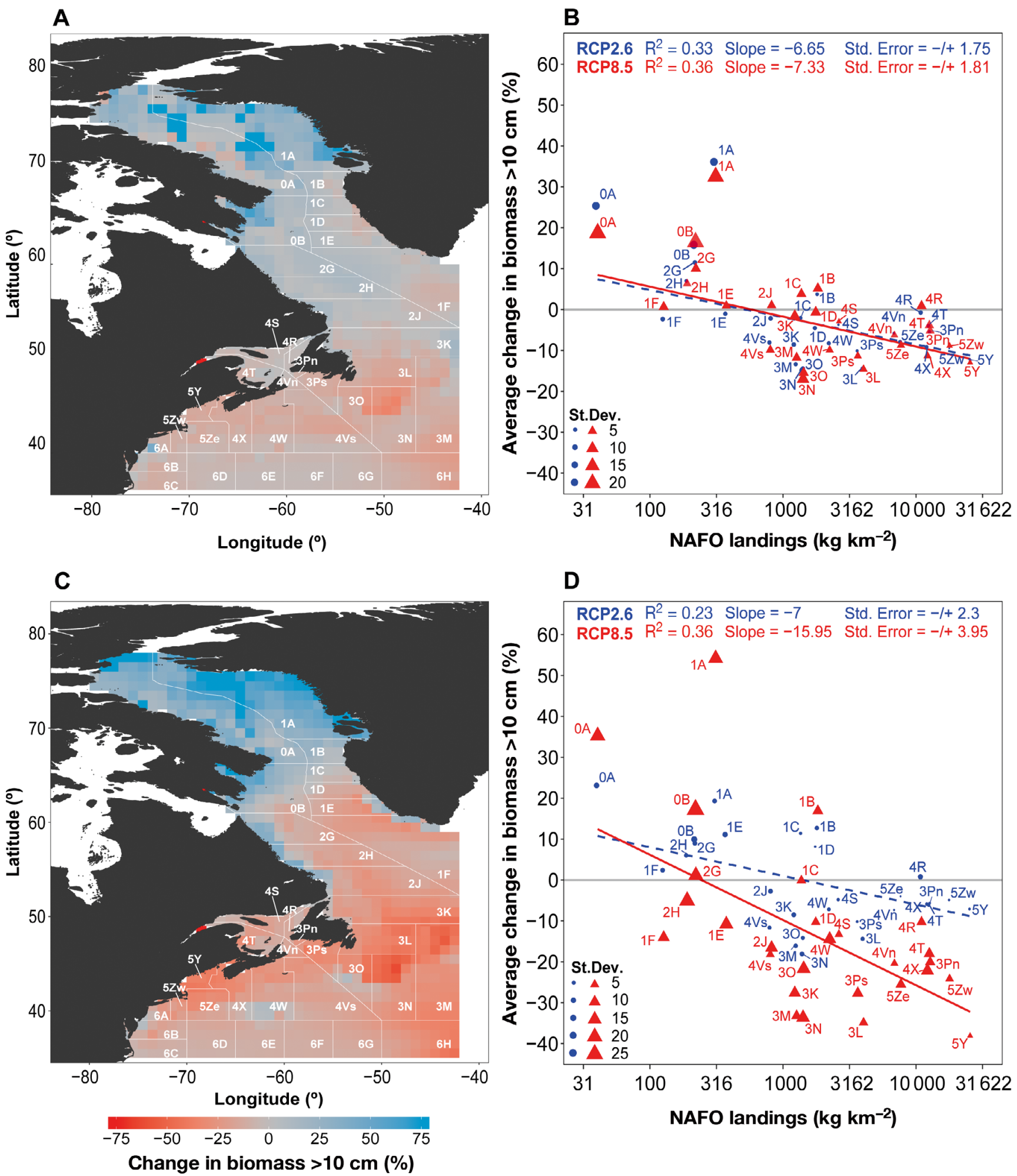

Fig. 3. Future ensemble mean changes (\%) in biomass of animals $>10 \mathrm{~cm}$ under RCP8.5 in the (A) 2030s and (C) $2090 \mathrm{~s}$ relative to the $1990 \mathrm{~s}$, and $(\mathrm{B}, \mathrm{D})$ their respective relationships to average annual fisheries landings in the $1990 \mathrm{~s}\left(\mathrm{~kg} \mathrm{~km}^{-2}\right)$ across individual NAFO divisions; (B) and (D) show inverse-variance weighted linear regressions. Number-letter combinations correspond to NAFO divisions in the maps. Landings values are presented on a log scale. Horizontal line: $0 \%$ change. Spatial results for projected biomass changes under RCP2.6 are shown in Fig. S3, and relationships with fisheries landings in the 1980s and 2000s in Fig. S4. Country shapefile retrieved from www.diva-gis.org/gdata; NAFO division shapefile retrieved from 

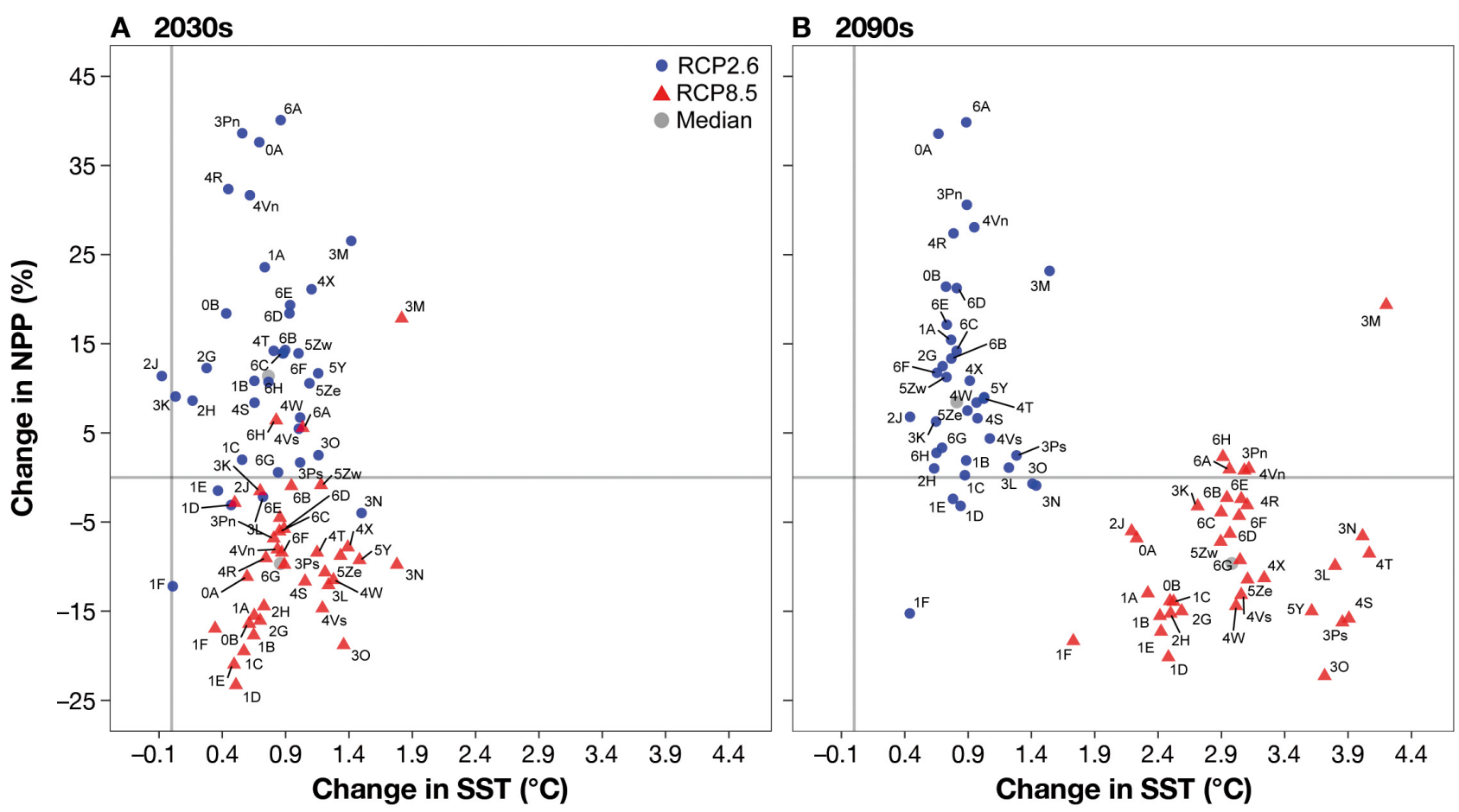

Fig. 4. Projected relative changes in net primary productivity (NPP) and sea surface temperature (SST) across Earth System Models $(\mathrm{n}=2)$ under RCP2.6 and RCP8.5 across individual NAFO divisions in the (A) 2030s and (B) 2090s relative to the 1990s. Number-letter combinations correspond to NAFO divisions in the maps in Fig. 3. Larger grey dots: median values of projected NPP and SSTs across the entire NAFO convention area; grey lines: $0 \%$ and $0^{\circ} \mathrm{C}$ change

By the 2030s, biomass under RCP2.6 was projected to decrease in most divisions, while some regions in the northern divisions $0 \mathrm{~A}-\mathrm{B}$ and $1 \mathrm{~A}$ showed projected biomass increases by up to $75 \%$ (Fig. S3A). The projected near-future biomass changes were similar under RCP8.5 (Fig. 3A). By the 2090s, biomass projections again showed similar patterns under RCP2.6 (Fig. S3C); however, expanding and exacerbated biomass declines were projected under RCP8.5 (Fig. 3C). Most of the NAFO convention area below $60^{\circ} \mathrm{N}$ was projected to experience large biomass declines $(-10$ to $-40 \%$ ), with peak declines in NAFO subarea 3, while biomass was projected to increase in NAFO divisions $0 \mathrm{~A}, 0 \mathrm{~B}, 1 \mathrm{~A}$, and $1 \mathrm{~B}$ (Fig. 3C).

The spatial trends in projected biomass changes generally corresponded to a combination of projected changes in NPP and SST generated by the Earth System Models (Fig. 4). In the near future (Fig. 4A), most NAFO divisions were projected to experience an SST increase of $<1^{\circ} \mathrm{C}$ (median $0.78^{\circ} \mathrm{C}$ under RCP2.6, $0.86^{\circ} \mathrm{C}$ under RCP8.5), with only few attaining values up to $1.5-1.8^{\circ} \mathrm{C}$ and only one area (Division 2J) showing a slight SST decrease under RCP2.6. However, the majority of NAFO divisions experienced an increase in NPP under RCP2.6 (85\% of NAFO divisions, median $12 \%$ change) but a decrease in NPP under RCP8.5 (94\% of NAFO divisions, median $-9.5 \%$ change). By the 2090s (Fig. 4B), there were distinct differences in both SST and NPP between RCP2.6 and RCP8.5. Under RCP2.6, projected SST changes were slightly greater (median $0.83^{\circ} \mathrm{C}$ ) and NPP changes lower (median $8.6 \%$ ) than those in the 2030s. Under RCP8.5, projected SST changes were much greater (median $3^{\circ} \mathrm{C}$ ), reaching $4^{\circ} \mathrm{C}$ in several divisions (e.g. $3 \mathrm{M}, 3 \mathrm{~N}, 3 \mathrm{Ps}, 4 \mathrm{~T}$, and $4 \mathrm{~S}$ ), while NPP mostly declined ( $86 \%$ of NAFO divisions, median $-9.5 \%$ ).

\subsection{Relationship of projected biomass changes to fisheries landings}

Projected biomass changes showed negative relationships with mean fisheries landings in the NAFO convention area, with similar slopes under both emissions scenarios in the near future (Fig. 3B) yet a more negative slope under RCP8.5 than RCP2.6 in the far future (Fig. 3D, Table S2). The variation around the analyzed relationship increased (SD around the slopes; Table S2), between near- and farfuture changes under both emission scenarios, while the fit (adj. $\mathrm{R}^{2}$ ) remained similar. 
Under RCP2.6 and RCP8.5, projected biomass decreased in most NAFO divisions with mean fisheries landings of $>1000 \mathrm{~kg} \mathrm{~km} \mathrm{~km}^{-2}$. Divisions that showed projected biomass increases included northern divisions (subarea 0, 1, and 2) with mostly lower mean landings (<1000 kg km-2 ; Fig. 3). Notably, by the 2090s, divisions with lower landings (i.e. 0A, 0B, and $1 \mathrm{~A})$ were projected to experience biomass increases between 20 and $70 \%$ under RCP8.5; however, most divisions with higher landings were projected to experience biomass decreases between 5 and $40 \%$ (Fig. 3D). Our sensitivity analyses also revealed negative relationships between projected biomass changes and mean landings in the 1980s and 2000s under both emissions scenarios for nearand far-future changes (Fig. S4) and corroborated the results of our selected 1990s time frame (Fig. 3), since the spatial distribution of mean landings across NAFO divisions did not differ substantially across the decades (Fig. S5).

\section{DISCUSSION}

This study highlights that climate change will have substantial impacts on marine ecosystems and the future of living marine resources in the North Atlantic Ocean, which will pose challenges for fisheries management. Understanding the magnitude of effects and their consequences is therefore critical for the development of sustainable fisheries into the future. Our ensemble projections revealed that the largest biomass changes and fisheries management challenges will manifest in the long term towards the end of the $21^{\text {st }}$ century and under the worst-case emissions scenario compared to the near-future (the 2030s) and strong-mitigation scenario. Moreover, our results highlight regional differences in the direction and magnitude of projected changes in marine animal biomass and underlying environmental drivers across NAFO divisions; projections show potential biomass increases and associated benefits in northern regions with historically low fisheries landings compared to biomass declines in more southern regions with historically high fisheries landings. Our ensemble modeling approach highlights regions with a strong agreement and low variability among individual model projections and regions with strong differences, which offers valuable insights into model uncertainties that can be used to improve individual Earth System and ecosystem models (e.g. their structure, processes, and resolution) and their utility to inform fisheries management.

\subsection{Projected changes in the North Atlantic Ocean}

Across the North Atlantic, spatial patterns of projected biomass changes were similar in the near (the 2030s) and far future (the 2090s); however, the magnitude of change increased over time and from strong mitigation (RCP2.6) to a worst-case (RCP8.5) scenario. These results demonstrate the potential benefits of climate-change mitigation under the Paris Agreement (UNFCCC 2015). Notably, regions above $60^{\circ} \mathrm{N}$ and off Northwest Africa were projected to experience large biomass increases, indicating emerging ecosystem conditions that favor oceanic productivity due to climate change, such as warming polar waters and increased primary production; however, the high variability and low model agreement in these regions, likely due to uncertainties in Earth System Model projections in polar and upwelling areas (Bopp et al. 2013), suggest a broad range of potential future trajectories. In contrast, nearshore waters along the North American East Coast, the UK and Ireland, and along the West African coastline are projected to experience overall biomass declines under both emissions scenarios, highlighting climatechange related decreases in marine ecosystem production related to warming-induced increased stratification and reduced primary production. In these regions, low model variability and high agreement suggest greater certainty in future trajectories.

The spatial patterns of projected biomass changes are concurrent with observed and projected changes in 2 key drivers of marine ecosystem dynamics temperature and primary production. In the North Atlantic, the highest rates of warming over the last 3 decades have been observed at the Gulf Stream Front and in the Labrador Sea in the west, and on the European continental shelf above $50^{\circ} \mathrm{N}$ in the east (Taboada \& Anadón 2012, Pershing et al. 2015), with consequences for nutrient cycling, phytoplankton concentrations, and fish recruitment (Boyce \& Worm 2015, Britten et al. 2016). For example, in Canada's Atlantic waters, rising temperatures and declining phytoplankton levels have already led to lower production potential over recent decades (Bernier et al. 2018); under RCP8.5, our results show continued high warming and NPP declines leading to substantial biomass decreases by 2100. In the North Sea, NPP has declined since the 1980s as a function of increasing SST and decreasing riverine nutrient input, leading to reduced higher trophic level biomass and fish stock recruitment (Capuzzo et al. 2018). Future projections suggest further NPP decreases by up to $70 \%$ by 2100 (Barange et al. 2018) 
and $10-60 \%$ decreases in the biomass of key commercial fish stocks within UK waters under RCP2.6 and RCP8.5 (Fernandes et al. 2017); our results project biomass decreases of at least $75 \%$ in several Northeast Atlantic areas including the Irish, Celtic, and North Seas.

Generally, our ensemble results agree with observed and projected spatial trends in North Atlantic ecosystems but highlight regional variation in biomass projections. This regional variation in biomass decreases and increases can help identify regions with disadvantages (losers) and benefits (winners), respectively, for fishery-dependent societies in terms of consequences for seafood supply, fisheries operations, and challenges for marine management and conservation (Blanchard et al. 2017, Greenan et al. 2018). Eventually, the socio-economic and environmental impacts of climate change will also depend on future trajectories of commercial fisheries, aquaculture, and other human activities, including their politically adaptive and mitigative capacities (Blanchard et al. 2017, Galbraith et al. 2017, Lotze et al. 2019).

\subsection{Projected changes in the NAFO convention area}

The NAFO convention area spans major fishing grounds along the coasts of the Northeast USA, Atlantic and Arctic Canada, and Greenland, which have supported people for centuries and longer. Our ensemble projections suggest substantial changes in future marine animal biomass across NAFO divisions, yet projected changes differed in magnitude and in some cases direction between the near (the 2030s) and far (the 2090s) future relative to the historical reference period (the 1990s) and between low- and high-emissions scenarios.

Projected biomass declines were consistently higher within NAFO divisions 3L-3O, which include the Grand Banks of Newfoundland and the Flemish Cap, historically 2 of the richest fishing grounds in the world, supported by constant mixing of the cold and nutrient-rich Labrador Current and the warm Gulf Stream (DFO 2012). Water temperatures in these regions are anticipated to increase by more than $3^{\circ} \mathrm{C}$ over the $21^{\text {st }}$ century (RCP8.5), likely related to changes in large-scale ocean circulation, in particular a northward expansion of the Subtropical Gyre or shift of the Gulf Stream (Saba et al. 2016, Greenan et al. 2018), with considerable impacts on this highly productive shelf ecosystem and the fish- eries it supports. Although warm-adapted species may move in from the south, projected decreases in NPP under RCP8.5 will limit possible secondary production. We caution, however, that projected changes in Northwest Atlantic circulation patterns remain uncertain due to the limited capability of Earth System Models to represent complex oceanographic processes within this region and for fine scales and coastal areas (Sgubin et al. 2017).

Within Northeast US waters (NAFO divisions 5Y, $5 Z w, 5 Z e, 6 A-6 D)$, our projections also suggest strong biomass declines, particularly under RCP8.5, related to declining NPP and increasing SST. Recent observations indicate clear distributional shifts in more than 30 commercial fish stocks that are consistent with warming (Nye et al. 2009). For example, in the Gulf of Maine, a substantial reduction in recruitment and increasing mortality rates in Atlantic cod Gadus morhua populations have been observed, due to extreme water temperatures (Pershing et al. 2015). In the future, major US Atlantic fish stocks are projected to decline due to changes in thermal habitats, especially after 2060 (Shackell et al. 2014). Some of these species will move into Canadian waters from the south, with cold-adapted invertebrate and fish species moving further north or towards deeper or more offshore waters in search of colder habitats (Pinsky et al. 2013, Shackell et al. 2014, Stortini et al. 2015). These changes will alter regional food-web structure and species composition. On the other hand, an influx of warm-water species from the south may have increased marine diversity and productivity within some regions of the US northeast in recent decades (Friedland et al. 2020).

In the northern NAFO divisions $0 \mathrm{~A}-0 \mathrm{~B}$ and $1 \mathrm{~A}-1 \mathrm{~B}$, which include Baffin Bay, the Davis Strait, and the Labrador Sea, our ensemble projected biomass increases by the 2090s under both emissions scenarios, indicating enhanced ocean production and poleward shifts of marine animals as new habitats become available. In recent decades, polar regions have been warming at some of the highest rates on the globe (Hoegh-Guldberg \& Bruno 2010), resulting in longer growing seasons for phytoplankton, increased primary production, and loss of sea ice, opening new habitats that sustain growth and survival for shifting species (Cheung et al. 2009, Frainer et al. 2017, Andrews et al. 2019). Overall, gradual to substantial changes in species distribution are expected by the 2030s and 2090s, respectively, which will affect animal biomass, species diversity, community organization, and ecosystem functions and services (Cheung et al. 2009, 2010, Worm \& Lotze 2016). 
Across the NAFO convention area, projected SST increased in most divisions under both emissions scenarios, whereas NPP mostly increased under RCP2.6 yet decreased under RCP8.5. Both water temperature and primary production are critical drivers of marine ecosystem dynamics and important forcing variables in our model ensemble (Bopp et al. 2013, Worm \& Lotze 2016, Tittensor et al. 2018a). Several other physical and biochemical factors are also influenced by climate change, such as $\mathrm{pH}$, oxygen concentration, salinity, and sea-ice cover, which were considered by some ecosystem models (Table 1) (Tittensor et al. 2018a). Interestingly, by the 2030s, projected changes in SST did not differ in magnitude between emissions scenarios; however, distinct differences between RCP2.6 and RCP8.5 were projected by the 2090s. These patterns highlight the importance of implementing long-term effective climate-change mitigation measures to avoid extreme ocean warming and potentially deleterious effects on marine ecosystems.

In NAFO divisions $3 \mathrm{~K}, 3 \mathrm{M}, 3 \mathrm{O}, 3 \mathrm{Pn}$, and $3 \mathrm{Ps}$, projected animal biomass declined despite increases in NPP under RCP2.6 (but decreases under RCP8.5) for both the 2030s and 2090s, which may indicate a response to increasing water temperatures, rather than nutrient or prey limitations. As individual ecosystem models differ in the configuration of fundamental structures, taxonomic groups, and ecological processes, this response within the model ensemble was likely influenced by size-structured models (BOATS, Macroecological, DPBM; see Table S1, Figs. S6 \& S7), which focus on metabolic rates and energy flow, leading to biomass projections responding strongly to SST changes (Jennings \& Collingridge 2015, Carrozza et al. 2016, BryndumBuchholz et al. 2019, Lotze et al. 2019). In NAFO subarea 5, strong negative biomass responses to declining NPP and increasing SST were projected under RCP8.5 both in the near and far future. Here, the ensemble projections were likely influenced by models that respond more strongly to a combination of temperature, NPP, and additional drivers, such as $\mathrm{pH}$ and oxygen, affecting habitat availability and species distribution (e.g. EcoOcean, DBEM; see Table S1, Figs. S6 \& S7, Lotze et al. 2019).

\subsection{Relationship of projected biomass changes to fisheries landings}

Climate change is already impacting regional and global fisheries and the societies that depend on them, driving the need for resilient and adaptive, ideally pro-active management solutions (e.g. Allison et al. 2009, Cheung et al. 2013, Free et al. 2019, Barange 2019). In the Northwest Atlantic, regional fisheries production is already responding to rising sea temperatures and is expected to continue to change with global warming (Cheung et al. 2010). For example, the Gulf of Maine (NAFO division 5Y) lobster fishery has been recording record-breaking landings; however, the warmer southern New England (NAFO divisions 5Zw and 6A) fisheries have collapsed (Le Bris et al. 2018). The differences between the 2 lobster fisheries were primarily attributed to differences in their management and aboveaverage increasing water temperatures (Le Bris et al. 2018). In Atlantic Canada, higher water temperatures favor lobster populations, which are rapidly increasing on the Scotian Shelf, whereas 2 other high-value but cold-water invertebrate species - the northern shrimp Pandalus borealis and northern snow crab Chionoecetes opilio-have been declining on the Scotian Shelf and Newfoundland-Labrador Shelf over the past decade (Bernier et al. 2018, DFO 2018a, 2019a). These examples highlight current and potential future challenges for fisheries management under rapidly changing ocean conditions.

Our ensemble projections indicate potential future trajectories of harvestable biomass under climate change relative to the $1990 \mathrm{~s}$, which we then compared to fishing levels in the 1990s within NAFO divisions. The nature of the relationships provides information about potential climate-driven future changes in animal biomass that may influence fisheries production and thus be relevant for managers. For instance, forecasted biomass declines in divisions with traditionally high fish landings may suggest that fisheries may become less productive, or that fishers may need to spatially shift fishing efforts as target species move into other divisions. Additionally, forecasted biomass in northern NAFO divisions, which were historically less exploited, largely increased, indicating that fisheries may become more productive in these divisions. Understanding how fish biomass will change relative to its historical distribution will be important to proactively manage the fisheries. Our ensemble models do not include fishing pressure or management effects on marine biomass, and no direct link between our biomass projections and fisheries landings was assumed. We expected more southern NAFO subareas $(3,4,5$, and 6$)$ to be more negatively affected by climate change, as these regions are in warmer, more temperate waters compared to the colder, more northern subareas $(0,1$, 
and 2). Our results corroborate these expectations; negative climate-change impacts on potential future harvestable biomass in southern divisions coincide with regions of traditionally higher fisheries landings, such as the Grand Banks of Newfoundland, the Scotian Shelf, and the Gulf of Maine, all of which are already reporting climate-change related fisheries harvest reductions (Pershing et al. 2015, DFO 2018a, 2019a, Bernier et al. 2018, Le Bris et al. 2018).

Interestingly, the relationship between projected biomass changes and historical fisheries landings remains very similar between the 2030s and 2090s under the strong-mitigation scenario (RCP2.6). Under the worst-case scenario (RCP8.5), however, the regression slopes differed compared to RCP2.6 as well as between near- and far-future changes, highlighting that long-term climate-change mitigation efforts are paramount to avoid extreme changes in future harvestable biomass and associated socio-economic implications for Northwest Atlantic fishing communities. Some fisheries may become less profitable as stocks become less productive or shift their distribution with climate change. In response, fishing effort may redistribute, which can lead to overfishing and exacerbated population declines if not adequately accounted for in fisheries management (Pinsky \& Fogarty 2012). Hence, future fisheries management frameworks will not only need to explicitly account for long-term climate-change effects on harvestable biomass, but also consider human responses to these changes (Pinsky \& Fogarty 2012).

\subsection{Implications for fisheries management}

How can we ensure the sustainability of commercial fisheries and targeted fish stocks under global change? This question applies to species and ecosystem conservation, but also to the adaptability and resilience of the institutions in charge of managing national and international fisheries (Rayfuse 2012, 2019). Given the current level of overfishing in many fisheries worldwide and the anticipated climatechange impacts on ocean productivity, this study underlines the need for climate-adaptive fisheries management, which includes proactive management strategies that aim to mitigate, adapt, or respond to climate-change impacts to achieve long-term fisheries sustainability on regional and global scales (Wilson et al. 2018, Barange 2019).

Our ensemble results highlight substantial climatechange induced biomass changes within most of the temperate North Atlantic and NAFO convention area under 2 contrasting emissions scenarios, indicating challenges for the long-term sustainable management of living marine resources. Management measures by regional and national fisheries management agencies must be fully integrated with a comprehensive scientific understanding of the ecological (and socio-economic) consequences of climate change and develop an increased ability to continually adapt to new ecological realities arising from changing environmental conditions (Miller et al. 2010, Rayfuse 2019). Our results may help to identify and evaluate climate-adaptation strategies, which is imperative to proactively develop fishery policies that facilitate required changes in current management systems (Mills et al. 2013). However, considering long-term natural and anthropogenic climate change in traditional fisheries sciences, such as stock assessments that guide management decisions, has proven difficult to implement (Pinsky \& Mantua 2014, Marshall et al. 2019).

In addition to our ensemble projections, finer scale regional or species-specific ecosystem models may be of value for some fisheries management frameworks, as most fishing effort occurs in coastal or shelf regions, and many fisheries are managed based on single-species stock assessments (Guiet et al. 2019, Marshall et al. 2019). For fisheries management frameworks to account for climate change, marine ecosystem models ideally need to provide spatially resolved, species-specific forecasts under different fishing mortality levels for a range of climate-change scenarios and time scales (e.g. seasonal, 2, 5, or $10 \mathrm{yr}$ ). Such forecasts could support management agencies, such as DFO, which is already providing seasonal forecasts of Pacific salmon production and associated fishing opportunities and consequences (DFO 2018b). When implemented at the appropriate spatial and temporal resolutions, utilizing marine ecosystem models within fisheries management frameworks can facilitate incorporating climate change into ecosystem monitoring, stock assessments, spatial management, international agreements, and management of emerging fisheries (Pinsky \& Mantua 2014). Our ensemble projections, for instance, indicate spatial shifts of harvestable biomass production suggesting potential future consequences for local fishing communities in terms of access and reduced catches (Greenan et al. 2018, Rogers et al. 2019). Such long-term projections may facilitate setting long-term management and conservation measures; for example, redefining stock boundaries as populations shift to enable more accurate stock assessments (Pinsky \& Mantua 2014). Fur- 
ther, boundaries of fisheries closures and marine conservation areas could, in some instances, be dynamically re-evaluated to ensure long-term effective management and conservation outcomes under global change (Tittensor et al. 2019).

\subsection{Limitations and future research}

Our ensemble projections carry certain limitations that need to be considered. First, individual global marine ecosystem models in our model ensemble did not resolve every grid cell in our study region due to different marine ecosystem models using their specific grids and land-sea masks. Generally, openocean regions had greater model coverage than nearshore, coastal regions (Fig. S1). Consequently, low model coverage in some coastal grid cells reduced the number of marine ecosystem models incorporated into the ensemble model mean. Nevertheless, our historical ensemble projections captured temporal variations of biomass levels within the NAFO region that reflect a substantial reduction of biomass in the early 1990s (Fig. S8).

Second, model projections based on global Earth System Models are often less reliable in coastal or polar regions (Bonan \& Doney 2018, Derksen et al. 2018), as their resolution can be too coarse to capture small-scale oceanic dynamics, such as varying mixing patterns, upwelling, open-ocean connection, and marginal sea currents (Holt et al. 2009, Tittensor et al. 2018a). However, they could be improved through increased spatial resolution or coordinated regional downscaling to capture small-scale dynamics (Holt et al. 2017, Stock et al. 2017). Moreover, future ensemble projections of marine ecosystems will likely be refined with the integration of fully 3-dimensional depth-resolved monthly biogeochemical variables provided through CMIP6 (Ruane et al. 2016, Tittensor et al. 2018a).

Third, fishing is an important human impact on marine ecosystems and will add to climate-induced stresses on global and regional scales (Frank et al. 2005, Pershing et al. 2015, Free et al. 2019). Given that spatially explicit future fisheries scenarios are yet unavailable for most models within Fish-MIP (Tittensor et al. 2018a), our study did not include any fishing effects, thus isolating the climate-change signal upon which fisheries impacts will be superimposed. Considering our focus on implications for fisheries management institutions, future fisheries scenarios should ideally recognize the complexities of fisheries management under global change, e.g. increasing fishing costs due to increasing energy costs and inefficient transboundary fish stock agreements due to geographical shifts of commercially targeted stocks (Maury et al. 2017, VanderZwaag et al. 2017, Tittensor et al. 2018a, Cheung et al. 2019). This remains a major challenge, especially in aligning any such scenarios to common socio-economic scenarios used to drive other sectors, such as the Shared Socioeconomic Pathways, that define alternative trajectories in society and ecosystems in a world without climate policies (O'Neill et al. 2014), or the Oceanic Socioeconomic Pathways addressing policy-relevant scenarios for future ocean uses (Maury et al. 2017). In addition to including dynamic fishing scenarios, future marine ecosystem model development should aim to incorporate other human drivers and regional stressors, such as freshwater runoff, nutrient loading, and habitat alteration, as well as marine conservation efforts (i.e. increasing coverage of marine protected areas), which are important influences in coastal fisheries (Murawski et al. 2005, Cabral et al. 2019).

Finally, the information provided by global and regional marine ecosystem models, such as projected marine animal biomass changes, can be directly incorporated in the scientific advice of fisheries management organizations. One approach, which has been proposed by DFO, is a conceptual risk assessment that incorporates climate-change related information into their science advice in context of stock assessments (DFO 2019b). This 'climate-change conditioned advice' identifies appropriate variables reflecting climate change that affect the dynamics of a resource and links these to the risk assessment component of the advice (DFO 2019b).

\section{CONCLUSIONS}

Our ensemble projections in the North Atlantic Ocean and within the NAFO convention area demonstrate substantial changes in future marine fish biomass with climate change. Our findings suggest benefits from effective climate-change mitigation under the Paris Agreement by keeping global temperature rise in this century well below $2{ }^{\circ} \mathrm{C}$ above pre-industrial levels. We identified a strong relationship between areas of projected future declines in harvestable biomass and historically important fishing grounds, such as the Grand Banks of Newfoundland, the Scotian Shelf, and the Gulf of Maine, indicating long-term challenges for the responsible management authorities. Understanding climate-change impacts on marine ecosystems and 
associated commercial fisheries provides an important link in achieving the UN's SDGs, as our oceans and their goods and services directly affect the progress in meeting the goals for food security (SDG1), livelihoods (SDG2), and well-being for a growing human population (SDG3), and for sustaining life below water (SDG14) (Singh et al. 2019).

Acknowledgements. We thank all marine ecosystem modelers who contributed to the Fish-MIP initiative, particularly E. Galbraith, J. Blanchard, O. Maury, S. Jennings, W. Cheung, T. Silva, D. Carozza, D. Bianchi, T. Eddy, N. Barrier, P. Verley, M. Coll, and J. Steenbeek for running Fish-MIP simulations and providing ecosystem model outputs; L. Bopp, J. Dunne, C. Stock, and T. Roy for providing Earth System Model outputs; and M. Büchner, J. Volkholz, and J. Schewe for technical support. We also thank N. Shackell for valuable discussions and comments. Financial support was provided by the German Federal Ministry of Education and Research (BMBF Grant No. 01LS1201A1) through the Inter-Sectoral Impact Model Intercomparison Project (ISIMIP). A.B.B. acknowledges financial support from the NSERC CREATE Transatlantic Ocean Science and Technology Program (TOSST); D.G.B. from the Ocean Frontier Institute (OFI); D.P.T. from the Jarislowsky Foundation and the Kanne Rasmussen Foundation, Denmark; and H.K.L. and V.C. from the Natural Sciences and Engineering Research Council (NSERC) of Canada (RGPIN-2014-04491 and RGPIN-201904901, respectively).

\section{LITERATURE CITED}

Allison EH, Perry AL, Badjeck MC, Adger WN and others (2009) Vulnerability of national economies to the impacts of climate change on fisheries. Fish Fish 10:173-196

Andrews AJ, Christiansen JS, Bhat S, Lynghammar A, Westgaard JI, Pampoulie C, Præbel K (2019) Boreal marine fauna from the Barents Sea disperse to Arctic Northeast Greenland. Sci Rep 9:5799

Barange M (2019) Avoiding misinterpretation of climate change projections of fish catches. ICES J Mar Sci 76: 1390-1392

Barange M, Bahri T, Beveridge MCM, Cochrane KL, FungeSmith S, Poulain F (eds) (2018) Impacts of climate change on fisheries and aquaculture: synthesis of current knowledge, adaptation and mitigation options. FAO Fisheries and Aquaculture Technical Paper No. 627. FAO, Rome

Bernier RY, Jamieson RE, Moore AM (2018) State of the Atlantic Ocean synthesis report. Can Tech Rep Fish Aquat Sci 3167:1-149

* Blanchard JL, Jennings S, Holmes R, Harle J and others (2012) Potential consequences of climate change for primary production and fish production in large marine ecosystems. Philos Trans R Soc B 367:2979-2989

Blanchard JL, Watson RA, Fulton EA, Cottrell RS and others (2017) Linked sustainability challenges and trade-offs among fisheries, aquaculture and agriculture. Nat Ecol Evol 1:1240-1249

Bonan GB, Doney SC (2018) Climate, ecosystems, and planetary futures: the challenge to predict life in Earth system models. Science 359:eaam8328
Bopp L, Resplandy L, Orr JC, Doney SC, Dunne JP, Gehlen M, Tjiputra J (2013) Multiple stressors of ocean ecosystems in the $21^{\text {st }}$ century: projections with CMIP5 models. Biogeosciences 10:6225-6245

Boyce DG, Worm B (2015) Patterns and ecological implications of historical marine phytoplankton change. Mar Ecol Prog Ser 534:251-272

* Britten GL, Dowd M, Worm B (2016) Changing recruitment capacity in global fish stocks. Proc Natl Acad Sci USA 113:134-139

Bryndum-Buchholz A, Tittensor DP, Blanchard JL, Cheung WW and others (2019) Twenty-first-century climate change impacts on marine animal biomass and ecosystem structure across ocean basins. Glob Change Biol 25: $459-472$

Cabral H, Fonseca V, Sousa T, Costa Leal M (2019) Synergistic effects of climate change and marine pollution: an overlooked interaction in coastal and estuarine areas. Int J Environ Res Public Health 16:2737

* Capuzzo E, Lynam CP, Barry J, Stephens D, Forster RM, Greenwood N, Engelhard GH (2018) A decline in primary production in the North Sea over 25 years, associated with reductions in zooplankton abundance and fish stock recruitment. Glob Change Biol 24:e352-e364

Carozza DA, Bianchi D, Galbraith ED (2016) The ecological module of BOATS-1.0: a bioenergetically constrained model of marine upper trophic levels suitable for studies of fisheries and ocean biogeochemistry. Geosci Model Dev 9:1545-1565

Castañeda RA, Burliuk CM, Casselman JM, Cooke SJ and others (2020) A brief history of fisheries in Canada. Fisheries 45:303-318

Cheung WW, Lam VW, Sarmiento JL, Kearney K, Watson R, Pauly D (2009) Projecting global marine biodiversity impacts under climate change scenarios. Fish Fish 10: 235-251

Cheung WW, Lam VW, Sarmiento JL, Kearney K, Watson REG, Zeller D, Pauly D (2010) Large-scale redistribution of maximum fisheries catch potential in the global ocean under climate change. Glob Change Biol 16:24-35

* Cheung WWL, Dunne J, Sarmiento JL, Pauly D (2011) Integrating ecophysiology and plankton dynamics into projected maximum fisheries catch potential under climate change in the Northeast Atlantic. ICES J Mar Sci 68: 1008-1018

* Cheung WW, Watson R, Pauly D (2013) Signature of ocean warming in global fisheries catch. Nature 497:365-368

Cheung WW, Lam VW, Ota Y, Swartz W (2019) Modelling future oceans: the present and emerging future of fish stocks and fisheries. In: Caddell R, Molenaar EJ (eds) Strengthening international fisheries law in an era of changing oceans. Bloomsbury Publishing, London, p $17-19$

Christensen V, Coll M, Buszowski J, Cheung WW and others (2015) The global ocean is an ecosystem: simulating marine life and fisheries. Glob Ecol Biogeogr 24:507-517

* Claret M, Galbraith ED, Palter JB, Bianchi D, Fennel K, Gilbert D, Dunne JP (2018) Rapid coastal deoxygenation due to ocean circulation shift in the northwest Atlantic. Nat Clim Chang 8:868-872

Costello C, Ovando D, Clavelle T, Strauss CK and others (2016) Global fishery prospects under contrasting management regimes. Proc Natl Acad Sci USA 113: 5125-5129

Derksen C, Burgess D, Duguay C, Howell S and others 
(2018) Changes in snow, ice, and permafrost across Canada. In: Bush E, Lemmen DS (eds) Canada's changing climate report. Government of Canada, Ottawa, p 194-260

DFO (2018a) An assessment of northern shrimp (Pandalus borealis) in Shrimp Fishing Areas 4-6 in 2017. DFO Can Sci Advis Sec Sci Advis Rep 2018/018

DFO (2018b) Preliminary 2019 salmon outlook. https://www. pac.dfo-mpo.gc.ca/pacific-smon-pacifique/science/ research-recherche/smon-outlook-perspective-eng.html (accessed 23 August 2020)

DFO (2019a) Assessment of Newfoundland and Labrador (Divisions 2HJ3KLNOP4R) snow crab. DFO Can Sci Advis Sec Sci Advis Rep 2019/041

DFO (2019b) Framework for incorporating climate-change considerations into fisheries stock assessments. DFO Can Sci Advis Sec Sci Advis Rep 2019/029

Dufresne JL, Foujols MA, Denvil S, Caubel A and others (2013) Climate change projections using the IPSL-CM5 Earth System Model: from CMIP3 to CMIP5. Clim Dyn 40:2123-2165

* Dunne JP, John JG, Adcroft AJ, Griffies SM and others (2012) GFDL's ESM2 global coupled climate-carbon earth system models. Part I: physical formulation and baseline simulation characteristics. J Clim 25:6646-6665

Fernandes JA, Papathanasopoulou E, Hattam C, Queirós AM, Cheung WW, Yool A, Calosi P (2017) Estimating the ecological, economic and social impacts of ocean acidification and warming on UK fisheries. Fish Fish 18:389-411

Frainer A, Primicerio R, Kortsch S, Aune M, Dolgov AV, Fossheim M, Aschan MM (2017) Climate-driven changes in functional biogeography of Arctic marine fish communities. Proc Natl Acad Sci USA 114:12202-12207

Frank KT, Petrie B, Choi JS, Leggett WC (2005) Trophic cascades in a formerly cod-dominated ecosystem. Science 308:1621-1623

Frank KT, Petrie B, Fisher JA, Leggett WC (2011) Transient dynamics of an altered large marine ecosystem. Nature 477:86-89

Free CM, Thorson JT, Pinsky ML, Oken KL, Wiedenmann J, Jensen OP (2019) Impacts of historical warming on marine fisheries production. Science 363:979-983

Friedland KD, Langan JA, Large SI, Selden RL, Link JS, Watson RA, Collie JS (2020) Changes in higher trophic level productivity, diversity and niche space in a rapidly warming continental shelf ecosystem. Sci Tot Environ 704:135270

Galbraith ED, Carozza DA, Bianchi D (2017) A coupled human-Earth model perspective on long-term trends in the global marine fishery. Nat Commun 8:14884

Greenan BJW, James TS, Loder JW, Pepin P and others (2018) Changes in oceans surrounding Canada. In: Bush E, Lemmen DS (eds) Canada's changing climate report. Government of Canada, Ottawa, p 343-423

Guiet J, Galbraith E, Kroodsma D, Worm B (2019) Seasonal variability in global industrial fishing effort. PLOS ONE 14:e0216819

*Hoegh-Guldberg O, Bruno JF (2010) The impact of climate change on the world's marine ecosystems. Science 328 : 1523-1528

Holt J, Harle J, Proctor R, Michel S and others (2009). Modelling the global coastal ocean. Philos Trans R Soc A 367 : 939-951

Holt J, Hyder P, Ashworth M, Harle J and others (2017) Prospects for improving the representation of coastal and shelf seas in global ocean models. Geosci Model Dev 10: 499-523

Jennings S, Collingridge K (2015) Predicting consumer biomass, size-structure, production, catch potential, responses to fishing and associated uncertainties in the world's marine ecosystems. PLOS ONE 10:e0133794

* Le Bris A, Mills KE, Wahle RA, Chen Y, Alexander MA, Allyn AJ, Pershing AJ (2018) Climate vulnerability and resilience in the most valuable North American fishery. Proc Natl Acad Sci USA 115:1831-1836

* Lotze HK, Tittensor DP, Bryndum-Buchholz A, Eddy TD and others (2019) Global ensemble projections reveal trophic amplification of ocean biomass declines with climate change. Proc Natl Acad Sci USA 116:12907-12912

*Marshall KN, Koehn LE, Levin PS, Essington TE, Jensen OP (2019) Inclusion of ecosystem information in US fish stock assessments suggests progress toward ecosystembased fisheries management. ICES J Mar Sci 76:1-9

*Maury O (2010) An overview of APECOSM, a spatialized mass balanced 'Apex Predators ECOSystem Model' to study physiologically structured tuna population dynamics in their ecosystem. Prog Oceanogr 84:113-117

* Maury O, Campling L, Arrizabalaga H, Aumont O and others (2017) From shared socio-economic pathways (SSPs) to oceanic system pathways (OSPs): building policy-relevant scenarios for global oceanic ecosystems and fisheries. Glob Environ Change 45:203-216

* Mcllgorm A, Hanna S, Knapp G, Le Floc'H P, Millerd F, Pan M (2010) How will climate change alter fishery governance? Insights from seven international case studies. Mar Policy 34:170-177

*Miller K, Charles A, Barange M, Brander K, Gallucci VF, Gasalla MA, Perry RI (2010) Climate change, uncertainty, and resilient fisheries: institutional responses through integrative science. Prog Oceanogr 87:338-346

Mills KE, Pershing AJ, Brown CJ, Chen Y and others (2013) Fisheries management in a changing climate: lessons from the 2012 ocean heat wave in the Northwest Atlantic. Oceanography (Wash DC) 26:191-195

* Mora C, Wei CL, Rollo A, Amaro T and others (2013) Biotic and human vulnerability to projected changes in ocean biogeochemistry over the $21^{\text {st }}$ century. PLOS Biol 11: e1001682

* Mullon C, Steinmetz F, Merino G, Fernandes JA, Cheung WWL, Butenschön M, Barange M (2016) Quantitative pathways for Northeast Atlantic fisheries based on climate, ecological-economic and governance modelling scenarios. Ecol Modell 320:273-291

Murawski SA, Wigley SE, Fogarty MJ, Rago PJ, Mountain DG (2005) Effort distribution and catch patterns adjacent to temperate MPAs. ICES J Mar Sci 62:1150-1167

Nye JA, Link JS, Hare JA, Overholtz WJ (2009) Changing spatial distribution of fish stocks in relation to climate and population size on the Northeast United States continental shelf. Mar Ecol Prog Ser 393:111-129

*'Neill BC, Kriegler E, Riahi K, Ebi KL and others (2014) A new scenario framework for climate change research: the concept of shared socioeconomic pathways. Clim Change 122:387-400

* Pedersen EJ, Thompson PL, Ball RA, Fortin MJ and others (2017) Signatures of the collapse and incipient recovery of an overexploited marine ecosystem. R Soc Open Sci 4: 170215

*Pedersen EJ, Koen-Alonso M, Tunney TD (2020) Detecting regime shifts in communities using estimated rates of 
change. ICES J Mar Sci 77:1546-1555

Pershing AJ, Alexander MA, Hernandez CM, Kerr LA and others (2015) Slow adaptation in the face of rapid warming leads to collapse of the Gulf of Maine cod fishery. Science 350:809-812

Pinsky ML, Fogarty M (2012) Lagged social-ecological responses to climate and range shifts in fisheries. Clim Change 115:883-891

Pinsky ML, Mantua NJ (2014) Emerging adaptation approaches for climate-ready fisheries management. Oceanography (Wash DC) 27:146-159

* Pinsky ML, Worm B, Fogarty MJ, Sarmiento JL, Levin SA (2013) Marine taxa track local climate velocities. Science 341:1239-1242

Poloczanska ES, Brown CJ, Sydeman WJ, Kiessling W and others (2013) Global imprint of climate change on marine life. Nat Clim Chang 3:919-925

Popova E, Yool A, Byfield V, Cochrane K, Coward AC, Salim SS, Sauer WH (2016) From global to regional and back again: common climate stressors of marine ecosystems relevant for adaptation across five ocean warming hotspots. Glob Change Biol 22:2038-2053

Ramírez F, Afán I, Davis LS, Chiaradia A (2017) Climate impacts on global hot spots of marine biodiversity. Sci Adv 3:e1601198

Rayfuse R (2012) Climate change and the law of the sea. In: Rayfuse R, Scott SV (eds) International law in the era of climate change. Edward Elgar, Cheltenham, p 147-174

Rayfuse R (2019) Addressing climate change impacts in Regional Fisheries Management organizations. In: Caddell R, Molenaar EJ (eds) Strengthening international fisheries law in an era of changing oceans. Bloomsbury Publishing, London, p 247-268

Riahi K, Rao S, Krey V, Cho C, Chirkov V and others (2011) RCP 8.5-a scenario of comparatively high greenhouse gas emissions. Clim Change 109:33

Rogers LA, Griffin R, Young T, Fuller E, Martin KS, Pinsky ML (2019) Shifting habitats expose fishing communities to risk under climate change. Nat Clim Chang 9:512-516

* Ruane AC, Teichmann C, Arnell NW, Carter TR and others (2016) The vulnerability, impacts, adaptation and climate services advisory board (VIACS AB v1. 0) contribution to CMIP6. Geosci Model Dev 9:3493-3515

Saba VS, Griffies SM, Anderson WG, Winton M and others (2016) Enhanced warming of the Northwest Atlantic Ocean under climate change. J Geophys Res Oceans 121:118-132

Sgubin G, Swingedouw D, Drijfhout S, Mary Y, Bennabi A (2017) Abrupt cooling over the North Atlantic in modern climate models. Nat Commun 8:14375

Shackell NL, Ricard D, Stortini C (2014) Thermal habitat index of many Northwest Atlantic temperate species stays neutral under warming projected for 2030 but

Editorial responsibility: Myron Peck, Hamburg, Germany changes radically by 2060. PLOS ONE 9:e90662

* Singh GG, Hilmi N, Bernhardt JR, Cisneros Montemayor AM and others (2019) Climate impacts on the ocean are making the Sustainable Development Goals a moving target travelling away from us. People Nat 1:317-330

Soomai SS (2017) The science-policy interface in fisheries management: insights about the influence of organizational structure and culture on information pathways. Mar Policy 81:53-63

Stock CA, John JG, Rykaczewski RR, Asch RG and others (2017) Reconciling fisheries catch and ocean productivity. Proc Natl Acad Sci USA 114:E1441-E1449

* Stortini CH, Shackell NL, Tyedmers P, Beazley K (2015) Assessing marine species vulnerability to projected warming on the Scotian Shelf, Canada. ICES J Mar Sci 72:1731-1743

*Taboada FG, Anadón R (2012) Patterns of change in sea surface temperature in the North Atlantic during the last three decades: beyond mean trends. Clim Change 115: 419-431

*Tittensor DP, Eddy TD, Lotze HK, Galbraith ED and others (2018a) A protocol for the intercomparison of marine fishery and ecosystem models: Fish-MIP v1.0. Geosci Model Dev 11:1421-1442

* Tittensor DP, Lotze HK, Eddy TD, Galbraith ED and others (2018b) ISIMIP2a simulation data from fisheries \& marine ecosystems (Fish-MIP; global) sector.

* Tittensor DP, Beger M, Boerder K, Boyce DG and others (2019) Integrating climate adaptation and biodiversity conservation in the global ocean. Sci Adv 5:eaay9969

Townsend DW, Thomas AC, Mayer LM, Thomas MA, Quinlan JA (2006) Oceanography of the northwest Atlantic continental shelf $(1$, W). In: Robinson AR, Brink KH (eds) The sea, Vol 14A. Harvard University Press, Cambridge, MA, p 119-168

UNFCCC (United Nations Framework Convention on Climate Change) (2015) Adoption of the Paris Agreement. http://unfccc.int/resource/docs/2015/cop21/eng/109r01. pdf (accessed 25 November 2019)

*van Vuuren DP, Edmonds J, Kainuma M, Riahi K and others (2011) The representative concentration pathways: an overview. Clim Change 109:5

*VanderZwaag DL, Bailey M, Shackell NL (2017) CanadaUS fisheries management in the Gulf of Maine: taking stock and charting future coordinates in the face of climate change. Ocean Yearb Online 31:1-26

*Wilson JR, Lomonico S, Bradley D, Sievanen L, Dempsey T, Bell M, Fitzgerald S (2018) Adaptive comanagement to achieve climate-ready fisheries. Conserv Lett 11:e12452

Worm B, Lotze HK (2016) Marine biodiversity and climate change. In: Letcher TM (ed) Climate change: observed impacts on Planet Earth, $2^{\text {nd }}$ edn. Elsevier, Amsterdam, p 195-212

Submitted: December 6, 2019; Accepted: July 22, 2020 Proofs received from author(s): August 23, 2020 